\title{
The epidermis of cyclopteroid Laveineopteris bohemica (Medullosales) from the Middle Pennsylvanian Radnice Member, Czech Republic
}

\author{
ZBYNĚK ŠIMUONEK \& CHRISTOPHER J. CLEAL
}

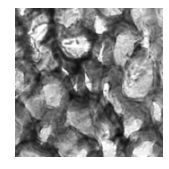

\begin{abstract}
The cyclopterids of the medullosalean Laveineopteris bohemica are most similar to those of Laveineopteris loshii, and clearly distinct from those of Laveineopteris rarinervis and Laveineopteris tenuifolia. The evidence supports the view that $L$. bohemica is a fossil-species of foliage of a distinct group of plants favouring the higher elevation wetlands of Variscan Euramerica. - Key words: Cyclopteris, Radnice Member, Pennsylvanian, Bolsovian, cuticular analysis, Kladno-Rakovník Basin.
\end{abstract}

S̆IMƯNEK, Z. \& CLEAL, C.J. 2013. The epidermis of cyclopteroid Laveineopteris bohemica (Medullosales) from the Middle Pennsylvanian Radnice Member, Czech Republic. Bulletin of Geosciences 88(1), 63-67 (3 figures, 1 table). Czech Geological Survey. ISSN 1214-1119. Manuscript received December 13, 2011; accepted in revised version July 13, 2012; published online August 15, 2012; issued December 6, 2012.

Zbynek Šimůnek, Czech Geological Survey, Klárov 131/3, 11821 Praha 1, Czech Republic; zbynek.simunek@geology.cz • Christopher J. Cleal, Department of Biodiversity Systematic Biology, National Museum Wales, Cathays Park, Cardiff CF10 3NP, UK

Laveineopteris Cleal et al., 1990 is a fossil-genus of medullosalean pteridosperm foliage that grew widely in the Early and Middle Pennsylvanian tropical wetlands of Euramerica. It includes both large, bifurcate semi-pinnate fronds (sensu Laveine 1997) and much smaller, entire leaves or foliar segments known as cyclopterids. According to Shute \& Cleal (2002), cyclopterids had the anatomical and morphological characteristics of shade leaves and were either attached to monopole saplings or epiphyllously to the basal parts of the bifurcate semi-pinnate fronds; the former cyclopterids were usually significantly larger than the latter. Laveine (2005) has in contrast argued that cyclopterids were merely modified pinnae attached to the proximal parts of the main frond, but this overlooks the quite different epidermal anatomy of the cyclopterids compared with the pinnate fronds, and the position of attachment of the cyclopterids (for a further discussion of the relationship between these cyclopterids and the pinnate foliage, see Cleal \& Shute 2012). Cleal \& Shute (2003) showed that the epidermal anatomy of the cyclopterid foliage is of considerable taxonomic importance in this genus as the cuticles of the pinnate foliage tend to be relatively characterless.

A recent systematic study of the imparipinnate neuropteroid foliage of the Radnice Member in the West and Central Bohemia Coal Basin described cuticles from most of the laveineopterid foliage found there (Šimůnek \&
Cleal 2011). At the time, however, we did not have available the cuticles from cyclopterids of one of the species, namely Laveineopteris bohemica (Ettingshausen) Šimůnek. Subsequently, a suitable specimen has come to light and the present paper documents its cuticles.

\section{Material and methods}

The hand specimen (Fig. 1) originated from the Ronna mine, Kladno, in the Kladno-Rakovník Basin in the Central Bohemian Region of the Czech Republic. The specimen was found by a private collector J. Haldovský and donated to the Czech Geological Survey, where it is stored under No. ZŠ 466. It was found in strata of the Radnice Member and is thus early Bolsovian in age in the Heerlen Regional Chronostratigraphy (Wagner 1977), probably approximating to an early Moscovian age in the IUGS Global Chronostratigraphical Scheme (Heckel \& Clayton 2006).

The cuticles were prepared by Z. Šimůnek using standard methods involving maceration in $40 \%$ Schulze Solution and then bleached using $10 \% \mathrm{KOH}$ solution (Barthel 1962, Cleal \& Zodrow 1989, Kerp 1991, Kerp \& Krings 1999). The cuticles were either mounted in glycerine jelly with stain added (safranin, Bismarck brown, malachite green or neutral red) for light microscopy, or mounted on a stub and coated with gold for SEM. 


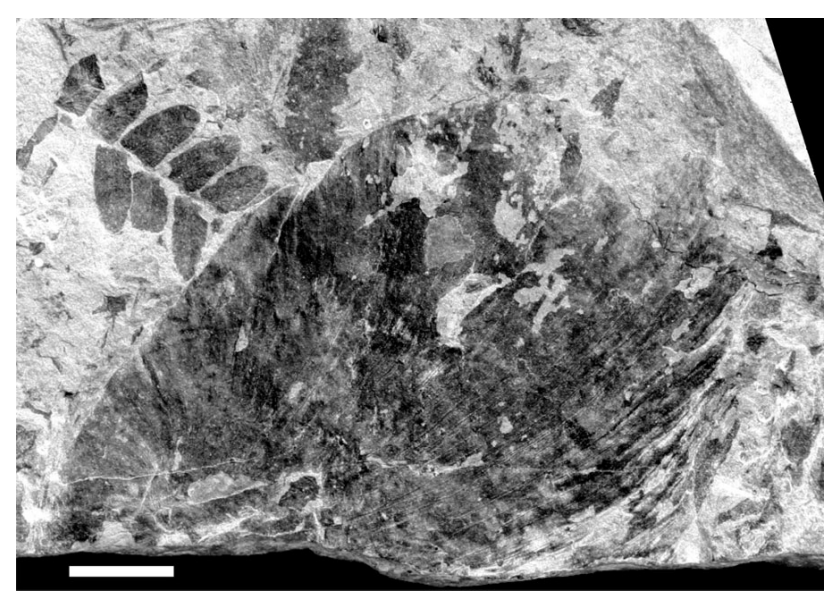

Figure 1. Hand specimen of Laveineopteris bohemica (Ettingshausen) Šimůnek, including both pinnate foliage, and the cyclopterid from which the cuticles were prepared. Ronna mine, Kladno; Radnice Member (Bolsovian Substage). Jan Haldovský Collection, Czech Geological Survey, No. Z $\breve{S} 466$. Scale bar $=10 \mathrm{~mm}$.

Descriptive nomenclature for the cuticles and epidermal anatomy follows Cleal \& Shute (2012).

\section{Systematic position}

A more complete account of the taxonomy of Laveineopteris bohemica can be found in Šimůnek \& Cleal (2011). Suffice it to say that it is conspecific with the specimens described from Upper Silesia by Gothan (1913) as Neuropteris nicolausiana Gothan and as Neuropteris nikolausii from Saar-Lorraine by Bertrand (1930) - these are merely orthographic variants of the same species name -, and the specimens from West and Central Bohemia described by Havlena (1953) as Neuropteris attenuata Lindley \& Hutton. It is unknown from the lowland, parallic basins of the Variscan Foreland.

\section{Description of cyclopterid cuticles}

What is here interpreted as the upper (adaxial) surface was thickly cutinised (Figs 2A, B, 3A). The upper epidermis consisted of rounded to polygonal, cells, mostly $25-40 \mu \mathrm{m}$ in size, with the positions of the anticlinal walls marked by thickly cutinised intercellular flanges. The cells in the intervein areas tended to be isodiametric; those along the veins were slightly elongate and arranged in longitudinal rows. The lower (abaxial) epidermis was more thinly cutinised (Fig. 2C-F) and consisted of irregular polygonal cells, with thinly but distinctly cutinised anticlinal walls. In the intervein area the cells were isodiametric, 40-60 $\mu \mathrm{m}$ in size; along the veins, the cells were elongate, 60-80 $\mu \mathrm{m}$ long and 25-35 $\mu \mathrm{m}$ wide.

Stomata were restricted to the intervein areas of the lower epidermis (Fig. 2C, E). The guard cells were slightly sunken, $15 \mu \mathrm{m}$ long and $\mathrm{ca} 2 \mu \mathrm{m}$ wide, and surrounded by two or sometimes three or four thickly cutinised lateral subsidiary cells, ca $20 \mu \mathrm{m}$ long and $10 \mu \mathrm{m}$ wide. The stomata were aligned approximately parallel to the veins. Stomatal density was $\mathrm{ca} 40$ per $\mathrm{mm}^{2}$; Stomatal Index ca 4.5 .

No hairs were preserved attached to either epidermis. On the upper epidermis there were very occasional cells with the periclinal wall uncutinised (Fig. 2B). On the lower surface circular to oval structures with a distinct rim, 20-30 $\mu \mathrm{m}$ in size, occurred in the central part of an epidermal cell (Figs 2C-F, 3B). In some cases these structures represented a complete hole in the cuticle (e.g. Fig. 2D, upper left; Fig. 2F, lower left), whereas in others the structure was partly covered by a thin cuticular membrane (Fig. 2F, lower right). There were $c a 45-50$ of these structured holes per $\mathrm{mm}^{2}$ on the lower surface of the cyclopterids.

\section{Discussion}

We now have detailed evidence of the epidermal anatomy of the cyclopterids of the five Laveineopteris species mostly commonly found in Variscan Euramerica (Table 1). They are all broadly similar in epidermal characters: stomata are predominantly on the lower surface and the stomatal density is very low; stomata have well-developed subsidiary cells; and both surfaces have holes that Shute \& Cleal (2003) interpreted as pores of active hydathodes. However, Laveineopteris bohemica most obviously distinguishes itself from the other taxa by the thickly cutinised upper surface, which appears to lack stomata and at most has only very sparse structured holes.

Laveineopteris bohemica is most similar in its cyclopterid epidermis to Laveineopteris loshii (Brongniart) Cleal et al., especially in the structure and distribution of

Figure 2. Cuticles of the cyclopterid of Laveineopteris bohemica (Ettingshausen) Šimůnek photographed under plain light. Ronna mine, Kladno; Radnice Member (Bolsovian Substage). $\bullet$ A - upper cuticle (Slide No. 548/3) showing thickly cutinised epidermal cells; scale bar $=100 \mu$ m. $\bullet$ B - close up of A, showing epidermal cell with uncutinised periclinal wall; scale bar $=25 \mu \mathrm{m}$. $\bullet \mathrm{C}-$ lower cuticle (Slide No. 548/2) showing sparse distribution of stomata and structured holes; scale bar $=100 \mu \mathrm{m}$. $\bullet \mathrm{D}$ - close-up of lower cuticle showing stomata with lateral subsidiary cells and structured holes; scale bar $=25 \mu \mathrm{m}$. $\bullet$ E - lower magnification view of $\mathrm{D}$; scale bar $=50 \mu \mathrm{m}$. $\bullet \mathrm{F}$ - close-up of $\mathrm{C}$ showing structured holes, including one partially covered by cuticle; scale bar $=25 \mu \mathrm{m}$. All photographs by Z. Šimůnek. 

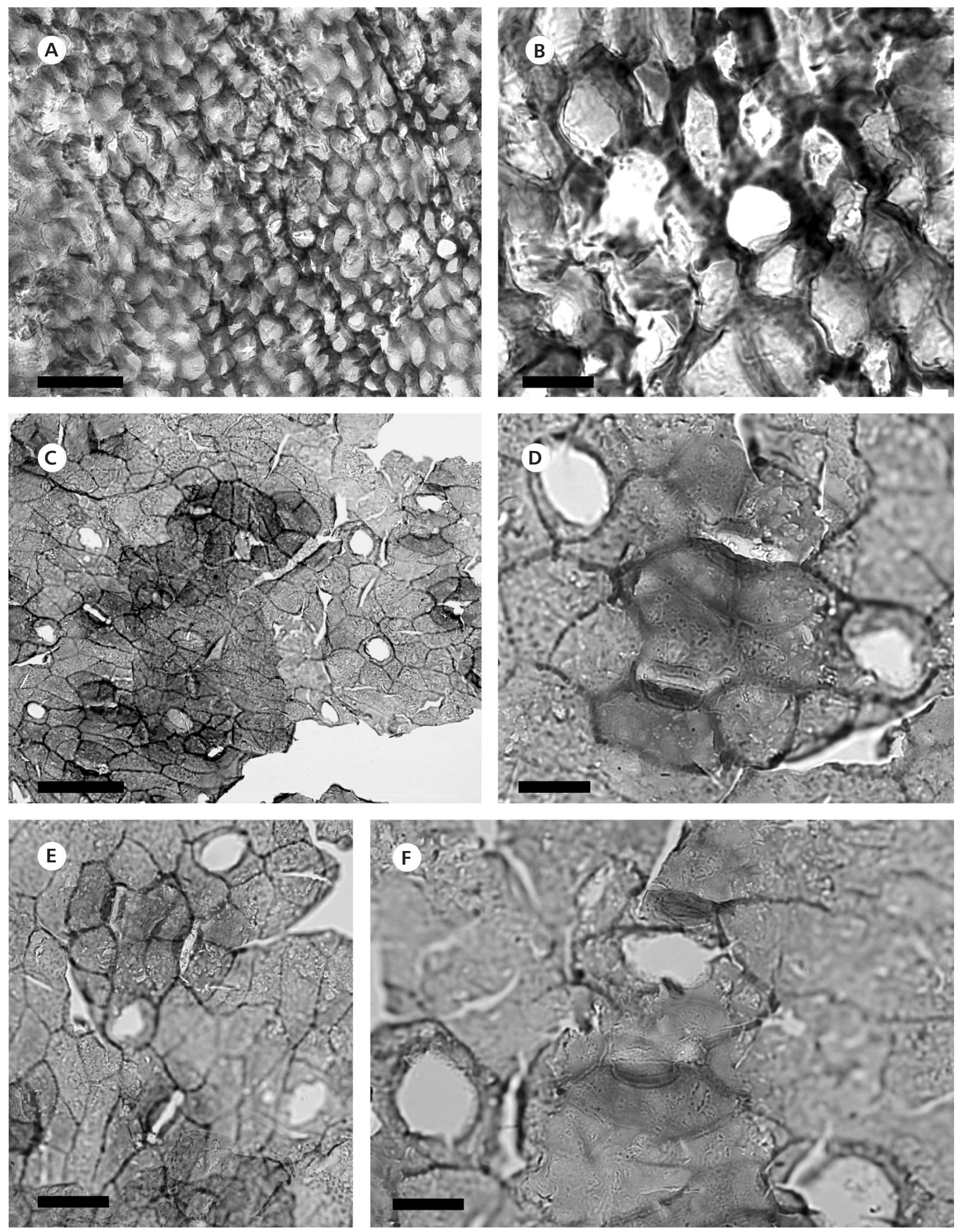

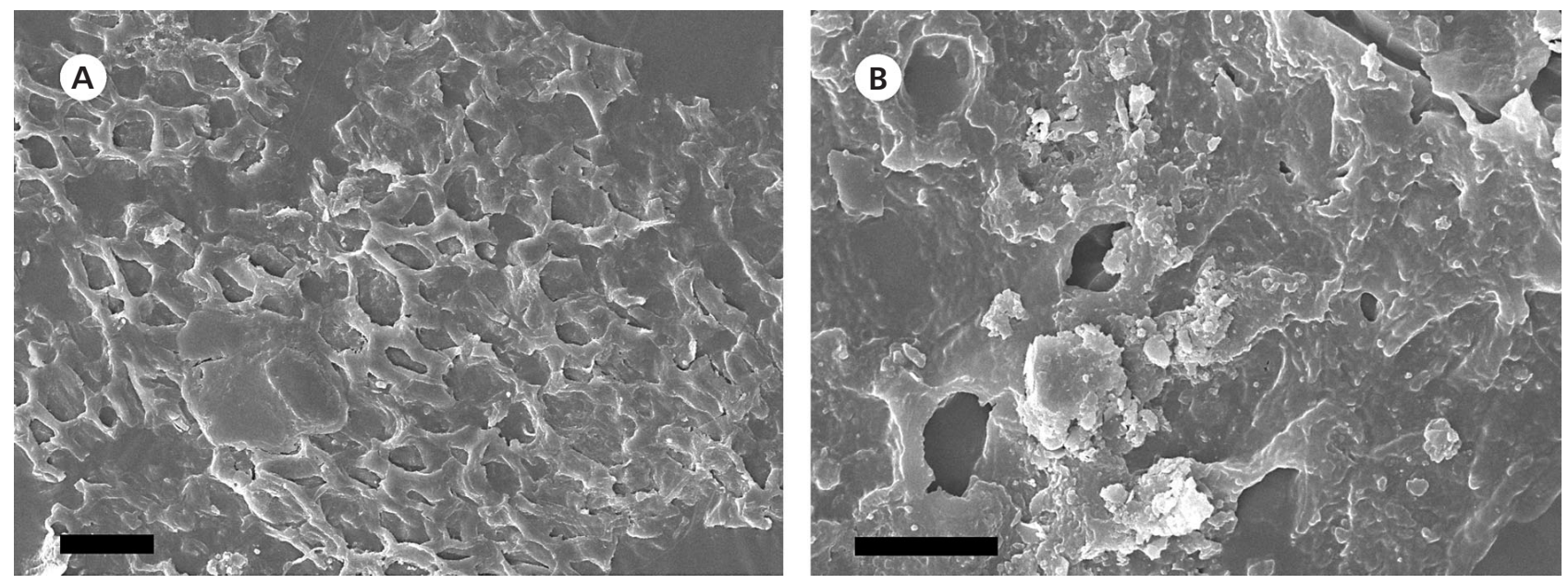

Figure 3. SEM images of cuticles of the cyclopterid of Laveineopteris bohemica (Ettingshausen) Šimůnek (SEM Stub No. 63). Ronna mine, Kladno; Radnice Member (Bolsovian Substage). $\bullet$ A - inner surface of upper cuticle showing thickly cutinised anticlinal walls; scale bar $=50 \mu \mathrm{m}$. $\bullet$ B - outer surface of lower cuticle showing structured holes; scale bar $=20 \mu \mathrm{m}$. All photographs by Z. Šimůnek.

Table 1. Cuticular characters for distinguishing the cyclopterids of the five most commonly found laveineopterid fossil-taxa. Modified from Cleal \& Shute (2003, table 1), with new data from Šimůnek \& Cleal (2011) and the present paper.

\begin{tabular}{|c|c|c|c|c|c|}
\hline & L. loshii & $\begin{array}{l}\text { L. tenuifolia } \text { var. } \\
\text { tenuifolia }\end{array}$ & $\begin{array}{l}\text { L. tenuifolia var. } \\
\text { nordfrancia }\end{array}$ & L. rarinervis & L. bohemica \\
\hline Stomatal distribution & Mainly lower surface & Mainly lower surface & Mainly lower surface & Mainly lower surface & Only lower surface \\
\hline $\begin{array}{l}\text { Stomatal density per } \mathrm{mm}^{2} \\
\text { (upper surface) }\end{array}$ & $4-10$ & Very low & 50 & 15 & - \\
\hline $\begin{array}{l}\text { Stomatal density per } \mathrm{mm}^{2} \\
\text { (lower surface) }\end{array}$ & $27-65$ & 25 & 70 & 35 & 40 \\
\hline Stomatal Index (lower surface) & $3.6-10.5$ & $5.5-8.5$ & $6.0-6.5$ & $?$ & 4.5 \\
\hline Polar subsidiary cells & Rare & 2 & $2-4$ & 2 & None \\
\hline Lateral subsidiary cells & $2-4$ & $\begin{array}{l}2 \text {, sometimes with } \\
\text { second pair of outer } \\
\text { laterals }\end{array}$ & $\begin{array}{l}2-4 \text {, sometimes with } \\
\text { an outer pair of laterals }\end{array}$ & $2-4$ & $2-4$ \\
\hline Cutinisation of subsidiary cells & Thick & Same as normal cells & Same as normal cells & Thick & Thick \\
\hline Hydathodes (upper surface) & $\begin{array}{l}\text { Structured holes } \\
\left(15-25 \text { per } \mathrm{mm}^{2}\right) \\
\text { mainly along veins }\end{array}$ & $\begin{array}{l}\text { Structured holes } \\
\left(35 \text { per } \mathrm{mm}^{2}\right) \text {, slightly } \\
\text { more dense along veins }\end{array}$ & $\begin{array}{l}\text { Structured holes } \\
\left(25-30 \text { per } \mathrm{mm}^{2}\right) \text {, } \\
\text { suniformly distributed }\end{array}$ & $\begin{array}{l}\text { Structured holes } \\
\left(20 \text { per } \mathrm{mm}^{2}\right) \text {, only } \\
\text { along veins }\end{array}$ & $\begin{array}{l}\text { (?)Structured holes, } \\
\text { very sparse }\end{array}$ \\
\hline Hydathodes (lower surface) & $\begin{array}{l}\text { Structured holes } \\
\left(15-25 \text { per } \mathrm{mm}^{2}\right) \\
\text { mainly along veins }\end{array}$ & $\begin{array}{l}\text { Ragged holes } \\
\left(7 \text { per } \mathrm{mm}^{2}\right) \text {, uniformly } \\
\text { distributed }\end{array}$ & $\begin{array}{l}\text { Structured holes } \\
\left(15-20 \text { per } \mathrm{mm}^{2}\right), \\
\text { uniformly distributed }\end{array}$ & $\begin{array}{l}\text { Structured holes } \\
\left(20 \text { per } \mathrm{mm}^{2}\right) \text {, } \\
\text { uniformly distributed }\end{array}$ & $\begin{array}{l}\text { Structured holes } \\
\left(40-50 \text { per } \mathrm{mm}^{2}\right) \text {, } \\
\text { uniformly distributed }\end{array}$ \\
\hline $\begin{array}{l}\text { Cutinisation of hydathodic } \\
\text { epidermal cells }\end{array}$ & Thick & Same as normal cells & Same as normal cells & Same as normal cells & Same as normal cells \\
\hline
\end{tabular}

the stomata, which have lateral subsidiary cells with thickly cutinised periclinal walls, and no or only poorly demarcated polar subsidiary cells. However, L. loshii can be distinguished by distinctive, thickly cutinised epidermal cells with structured holes (interpreted by Shute \& Cleal 2002 and Cleal \& Shute 2003, 2012 as active hydathodes) as well as the thick cutinisation of the upper epidermis.

Laveineopteris tenuifolia (Sternberg) Cleal et al. var. tenuifolia, Laveineopteris tenuifolia var. nordfrancia (Bertrand) Cleal \& Shute) and Laveineopteris rarinervis (Bunbury) Cleal et al. can all be clearly distinguished from
L. bohemica by the cyclopterid stomata, which normally have distinct polar subsidiary cells, and which occur on both surfaces (albeit more abundantly on the lower surface). The two varieties of $L$. tenuifolia can also be distinguished from L. bohemica by the stomatal subsidiary cells not having thickly cutinised periclinal walls.

Stockmans (1933) and Laveine (1967) argued that Laveineopteris bohemica and Laveineopteris rarinervis were conspecific, but the clear differences in their cyclopterid epidermal structures do not support this view. It instead supports the view of Havlena (1953), Cleal (2008) 
and Šimůnek \& Cleal (2011) that L. bohemica represents foliage of a distinctive medullosalean species of the higher elevation wetland vegetation of Variscan Euramerica.

\section{Acknowledgements}

The research was conducted with support of the Grant Agency of the Czech Republic (205/05/2034, P210/10/0232) and Research Aim of the Czech Geological Survey (MZP0002579801). The authors thank Jan Haldovský (Pchery, near Kladno) for donating the specimen for study.

\section{References}

BARTHEL, M. 1962. Epidermisuntersuchungen an einigen inkohlten Pteridospermenblättern des Oberkarbons und Perms. Geologie, Beiheft 33, 1-140.

BertrAnd, P. 1930. Bassin houiller de la Sarre et de la Lorraine. I. Flore fossile. 1er Fascicule Neuroptéridées. Études des Gîtes Minéraux de la France, 58 pp.

Cleal, C.J. 2008. Palaeofloristics of Middle Pennsylvanian medullosaleans in Variscan Euramerica. Palaeogeography, Palaeoclimatology, Palaeoecology 268, 164-180. DOI 10.1016/j.palaeo.2008.03.045

Cleal, C.J. \& Shute, C.H. 2003. Systematics of the Late Carboniferous medullosalean pteridosperm Laveineopteris and its associated Cyclopteris leaves. Palaeontology 46, 353-411. DOI 10.1111/1475-4983.00303

Cleal, C.J. \& Shute, C.H. 2012. The systematic and palaeoecological value of foliage anatomy in Late Palaeozoic medullosalean seed-plants. Journal of Systematic Palaeontology. DOI 10.1080/14772019.2011.634442

Cleal, C.J., Shute, C.H. \& Zodrow, E.L. 1990. A revised taxonomy for Palaeozoic neuropterid foliage. Taxon 39, 486-492. DOI $10.2307 / 1223109$

Cleal, C.J. \& Zodrow, E.L. 1989. Epidermal structure of some medullosan Neuropteris foliage from the middle and upper Carboniferous of Canada and Germany. Palaeontology 32, 837-882.

Gothan, W. 1913. Die oberschlesische Steinkohlenflora. 1. Teil.
Abhandlungen der Königlich Preussischen Geologischen Landesanstalt, Neue Folge 75, 1-278.

Havlena, V. 1953. Neuropteridy českého karbonu a permu. Rozpravy Ústředního ústavu geologického 16, 1-168.

Heckel, P.H. \& Clayton, G. 2006. The Carboniferous System. Use of the new official names for the subsystems, series and stages. Geologica Acta 4, 403-407.

KerP, H. 1991. The study of fossil gymnosperms by means of cuticular analysis. Palaios 5, 548-569.

DOI $10.2307 / 3514861$

KeRP, H. \& KRINGS, M. 1999. Light microscopy of cuticles, 52-56. In Jones, T.P. \& Rowe, N.P. (eds) Fossil plants and spores: modern techniques. Geological Society, London.

Laveine, J.-P. 1967. Contribution à l'étude de la flore du terrain houiller. Les Neuroptéridées du Nord de la France. Études Géologiques pour l'Atlas de Topographie Souterraine, Houillères du bassin du Nord et du Pas-de-Calais. Service géologique 1(5), 1-344.

Laveine, J.-P. 1997. Synthetic analysis of the neuropterids. Their interest for the decipherment of Carboniferous palaeogeography. Review of Palaeobotany and Palynology 95, 155-189. DOI 10.1016/S0034-6667(96)00033-4

LAVEINE, J.-P. 2005. The Cyclopteris of Laveineopteris (Late Carboniferous pteridosperm). Fancies and facts: methodological and taxonomical implications. Revue de Paléobiologie 24, 403-487.

Shute, C.H. \& Cleal, C.J. 2002. Ecology and growth habit of Laveineopteris: a gymnosperm from the Late Carboniferous tropical rain forests. Palaeontology 45, 943-972. DOI 10.1111/1475-4983.00270

ŠIMƯNEK, Z. \& CLEAL, C.J. 2011. Imparipinnate neuropteroid foliage (Medullosales) from the middle Westphalian of the West and Central Bohemia Coal Basin, Czech Republic. Review of Palaeobotany and Palynology 166, 163-201.

DOI 10.1016/j.revpalbo.2011.05.005

Stockmans, F. 1933. Les Neuroptéridées des bassins houiller belges (première partie). Mémoires de Musée Royal d'Histoire Naturelle de Belgique 57, 1-61.

WAGNER, R.H. 1977. Comments on the upper Westphalian and Stephanian floras of Czechoslovakia, with particular reference to their stratigraphic age, 441-457. In HoLuB, V.M. \& WAGNER, R.H. (eds) Symposium on Carbononiferous Stratigraphy. Geological Survey, Prague. 